\title{
Chapter 10. Why Uzbekistan and Kazakhstan are not Singapore: Comparing the first 25 years of reforms
}

\author{
Alexandr Akimov \\ Senior Lecturer in Banking and Finance, Griffith University, Australia \\ Email: a.akimov@griffith.edu.au
}

\begin{abstract}
After the collapse of the USSR, Uzbekistan and Kazakhstan have gradually developed into countries with strongly authoritarian presidential powers. The leaders of both countries, at various stages, have ruled out Western democracy as a suitable model. Instead, they have extensively used examples of authoritarian leadership and economic policies from Asia to justify their approach to political and economic affairs. In this chapter, the reforms undertaken by Uzbek and Kazakh leaders in the first 25 years of their independence are compared with the key reforms put forward by Singaporean post-independence leader Lee Kuan Yew, concluding with a discussion of why Uzbekistan and Kazakhstan have been unable to match Singapore's rapid development.
\end{abstract}

Key words: Uzbekistan, Kazakhstan, Singapore, political economy, reforms

\section{Introduction}

This year we are approaching the significant milestone of thirty years since the fall of the Berlin Wall. The world now is very different from that of thirty years ago. No longer is there a competition between two 'poles' of global affairs - the USA and the USSR. Indeed, after the collapse of the USSR, the hegemony of the remaining 'pole' - the USA - is being challenged, whether it is by China, Putin's Russia, or internally by President Trump's administration.

Against this backdrop, two ex-Soviet countries, Kazakhstan and Uzbekistan, that have transitioned towards authoritarian regimes under the leaderships of their respective presidents, have faced new challenges. Uzbekistan's president, Islam Karimov, who had led the country since independence, died in September 2016, while Kazakhstan's first president, Nursultan Nazarbayev, stepped down from his role in March 2019.

The countries they ruled shared many things in common - geographic location, cultural traditions, religion, language, and a post-Soviet heritage. Similarly, the two statesmen shared many things: a career in the Communist Party and Soviet industry, a vision for the prosperity of the countries they led and, to a certain degree, an approach to nation-building. Both leaders have rejected the idea of implementing Western-style democratization, claiming its unsuitedness to the mentality of their local populations. In this regard, they are not dissimilar to prominent Singaporean leader Lee Kuan Yew, to whose style both leaders explicitly or implicitly aspire.

The approach to economic and governance reforms in Uzbekistan and Kazakhstan has differed, which has led to variation in outcomes for the economic development of the two countries. What is clear, though, is that reforms under neither leader have brought the Singaporean-style economic prosperity they envisioned for their countries in the early years of independence. 
This chapter aims to assess the legacy of both leaders from a political economy point of view, with Lee Kuan Yew's leadership and the economic outcomes in Singapore serving as a benchmark. The chapter consists of five main parts. In the next section, the appropriateness of benchmarking Karimov's and Nazarbayev's leaderships against that of Lee Kuan Yew is discussed. In particular, the initial political, economic, demographic and social conditions in these countries at the time of independence are reviewed, followed by examination of the main leadership ideas adopted. In the third section, the key criteria for successful reform in Singapore in terms of political changes, governance and economic reforms are established. In the fourth section, Uzbekistan's and Kazakhstan's reforms are assessed against these key criteria. Finally, the economic and social outcomes in Kazakhstan and Uzbekistan following 25 years of transition are summarized and the main reasons for not achieving their aspirational goals are hypothesized. In conclusion, I consider whether the legacy of Lee Kuan Yew is still alive in Uzbekistan and Kazakhstan, and whether there is an opportunity to 'reset' the reform agenda.

\section{Are Uzbekistan and Kazakhstan comparable to Singapore?}

To be able to analyse the successes or failures in any comparative work, one essential component is the choice of an appropriate benchmark. Unfortunately, perfect benchmarks are a rarity in the real world, and this is especially true when we want to compare countries; no two countries have the same history, demographics, climate, natural resources, and economic or legal environments. Leaders in both Uzbekistan and Kazakhstan chose personal political domination in the landscapes of their respective countries as their modus operandi. Akimov (2015) used Wintrobe's (1998) classification to assess the authoritarian regimes in Kazakhstan and Uzbekistan, concluding that Karimov's leadership matched most closely to a 'totalitarian regime', whereas Nazarbayev's had elements of both 'timocracy' and 'totalitarianism', with a gradual tendency to the latter as time progressed. Therefore, from the political economy point of view, it would be appropriate to compare the first 25 post-independence years with a country or countries that have been successful while also having an authoritarian leader in charge. Although there was an abundance of the latter, the choice of those that could also be deemed a success was very limited. The country that appears to offer the best fit is Singapore, which leapt from being 'a Third World country' at the time of separation from Malaysia to become a 'First World' country in the 1990s under the strong leadership of Lee Kuan Yew. There is a debate among some authors (e.g. Josey, 1980, p. 232; Milne \& Mauzy, 1990, p. 105) as to whether Lee Kuan Yew's term in office should be classified as a dictatorship or could be regarded as a team effort, albeit a team he built around himself. However, there is no doubt that Lee's style of leadership has been rather authoritarian and has created the closest regime that we have had in recent history to what we could call a 'benevolent dictatorship' (Wintrobe, 1998, p. 14).

In his approach, President Nazarbayev has openly aspired to the leadership style of Lee Kuan Yew, mentioning Singapore's founding leader as a 'personal example' to him (Nazarbayev, 2006, p. 11). Moreover, Nazarbayev (2006, pp. 28, 30, 39, 205) emphasized on numerous occasions that he was keen to learn many aspects of Singapore's transformation strategy. By contrast, President Karimov of Uzbekistan never explicitly mentioned Singapore as a prime model for Uzbekistan's development path, but has cited the impressive growth of the new industrialized economies, which include Singapore, as an important experience to study. Moreover, he emphasized the important role of government in promoting economic growth and ensuring social stability in such countries (Karimov, 1996e, p. 276). The principle has been adopted in Karimov's own 'model for economic reforms' (Karimov, 1996d, pp. 166-167; 1996e, pp. 294-299). Moreover, Karimov's rejection of Western liberal democracy in its purest form for Uzbekistan is very similar to that of Lee Kuan Yew. Karimov, from the outset, emphasized that the democratic principles to be adopted should be adjusted to national culture 
and traditions (Karimov, 1996f, p. 44). This resonates well with Lee's view of Singapore's Confucian values and how democratic principles should be aligned with those values in countries like Singapore (Lee, 2000, pp. 490-496).

\section{Initial conditions}

At the time of independence, Uzbekistan and Kazakhstan enjoyed many similarities with Singapore. Firstly, the way in which the countries became independent was not dissimilar.

Prior to independence, Singapore was a colony of the British Empire. Nationalistic movement in the 1950s resulted in greater independence from the British, especially after the election into government in 1959 of the People's Action Party (PAP) led by Lee Kuan Yew. At that time, the Singaporean leadership did not envision Singapore as an independent state but rather a part of a larger, independent Malaya. This became a reality with the Malaysia Agreement of 1963.

Prior to the communist revolution in 1917, the territories of Kazakhstan and Uzbekistan were part of the Russian Empire. They became republics of the Soviet Union following Lenin's national delimitation policy in the 1920s. At the end of the 1980s, not dissimilarly to the rest of the Soviet Union, nationalist movements for greater autonomy occurred in both republics. Despite the de facto secession of the Baltic States in 1991, both Nazarbayev and Karimov, then leaders of the Communist Party in their respective republics, saw themselves in a revised union with Russia (in the form of the Union of Sovereign States). The rapid disintegration of the Soviet Union in 1991 came as a surprise to many, including the leaders of both republics, and meant that they had to start a process of nation-building from the beginning without any preparation. The story was similar in Singapore, where an unexpected independence arrived after the sudden expulsion of the region from the union with Malaysia in 1965.

At independence, Singapore had to deal with tricky ethnic issues. The country was multiethnic, with large Chinese, Malay and Tamil groups. An important task was to maintain interethnic peace and stability in the country. Moreover, these large ethnic groups felt strong allegiances to neighbouring China and Malaysia. A key challenge was to make all groups feel Singaporean.

Both Kazakhstan and Uzbekistan were multi-ethnic communities too. Sizeable ethnic minorities, especially Russians who had a strong sense of allegiance to Russia, also posed a challenge for the respective republics in their efforts to maintain unity. The problem was particularly pronounced in Kazakhstan where ethnic Russians accounted for nearly half of the pre-independence population. What was different in these republics, in contrast to Singapore, was that their ethnic majorities were indigenous to the region.

The process of disintegration is never without harmful effects on trade and economy. Singapore had to deal with deteriorated trade relationships with Malaysia and inherited tensions with Indonesia, its primary neighbours. Moreover, the gradual withdrawal of British political and economic interests was posing additional difficulties to the country.

Likewise, both Kazakhstan and Uzbekistan suffered from broken economic ties with other Soviet republics, because all such republics' economies had been elements in the flow of goods and services designed by Soviet planners. Although there were no major political obstacles to continuing trade relationships between the countries, technical problems resulting from new borders and a lack of unified enforceable rules harmed the economies of the republics dramatically.

As well as such similarities, key differences should be noted too. Singapore had long served as an entrepôt in the South-East Asian region and was therefore exposed to varying cultures, having trade ties with many countries both inside and outside of the region. The economy of 
the region was based on market forces, with good legal institutions and public administration to support the market economy inherited from the British. In contrast, Kazakhstan and Uzbekistan had hardly any experience of trading with the outside world, because all external trade flows had to be processed through relevant departments in Moscow. After more than 70 years of communism, there was little left that resembled a market economy, and no institutions to support one. Both the populations and the leaderships of the republics effectively had to learn about market principles from scratch.

Geographic location was also highly favourable to Singapore, it being a natural hub for regional trade routes in shipping and air transport. Its natural deep-sea port was a major reason for British interest in establishing a trading post there in the first place. This geographic advantage has allowed Singapore to rapidly mitigate its awkward relationships with Malaysia and Indonesia immediately following independence. In contrast, both Kazakhstan and Uzbekistan lack access to the sea, which constrains their ability to trade with the rest of the world. Moreover, instability in next-door Afghanistan rendered routes to southern ports unavailable for trade. Northern and north-western trading routes had to go through Russia, which was itself in economic turmoil. The only alternative, at the time, was a new eastern route and trade with China, albeit through its less developed regions. Uzbekistan, in particular, suffered from being a double-landlocked country, having to cross two borders to access any ports: trading routes to its north and east had first to go through Kazakhstan before they could reach Russia or China ${ }^{1}$.

There is also a vast difference in size between Singapore and Kazakhstan and Uzbekistan, both in terms of population but even more so in terms of land area, Singapore effectively being a city-state. Thus, Deng Xiaoping, in conversation with Lee Kuan Yew, commented, 'If I had only Shanghai, I might be able to develop Shanghai as quickly [as Singapore]. But I have the whole of China!' (Lee, 2000, p. 602). Furthermore, Uzbekistan and Kazakhstan had to deal with their unevenly developed regions and local peculiarities, as well as with the socioeconomic problems of rural communities and their migration to the cities.

However, in contrast to Singapore, which had no natural resources, Uzbekistan and, in particular, Kazakhstan were generously endowed with mineral resources. Moreover, as a result of universal schooling, healthcare and housing policy in the ex-USSR, both Uzbekistan and Kazakhstan had near-perfect literacy ratios and no pressing housing problems to manage. This allowed both countries the opportunity to address more pressing issues.

\section{Key principles of successful reforms in Singapore}

Academic commentators have pointed at a variety of drivers that enabled the successful transition of Singapore from a Third World colonial region to a prosperous First World country (Lee, 2000; Neo \& Chen, 2007; Root, 1996; Wirtz \& Chung, 2006; Yusuf \& Nabeshima, 2002). However, the influence of the following factors is unequivocal:

(i) good governance and political stability;

(ii) investments in human capital;

(iii) smart growth-oriented economic policies.

A premise for any government in undertaking difficult reforms is its legitimacy and political stability. Lee Kuan Yew used existing British-based political institutions to come to power in 1959 on an anti-colonial platform as one of the leaders of the PAP. Originally, the party was a mixture of people with a variety of ideas, united by anti-colonialism. It had a strong communist faction, including trade union leaders and members. Being himself a moderate, Lee had to ensure that his party's ideas appealed to a public with whom communist ideas were very

\footnotetext{
${ }^{1}$ China can also be reached via mountainous regions in Kyrgyzstan or Tajikistan.
} 
popular at the time. However, over time, Lee succeeded in removing extreme leftists from the party ranks. From independence in 1965, Lee and the PAP's leadership pursued a so-called 'survival' ideology, based on the principles of pragmatism, meritocracy, multiracialism and Asian values (Tremewan, 1996, p. 105). Until Lee Kuan Yew's retirement in 1991, the party won all the elections with a supermajority and no more than two seats going to the opposition. This dominance, unusual for liberal democracies, came from the genuine popularity of the PAP as a result of effective government policies, strong economic performance, political stability and lack of corruption. As Milne and Mauzy (1990, p. 96) noted, 'Elections in Singapore have the reputation of being scrupulously honest, which enhances legitimacy. There is no ballotrigging, intimidation of voters, inaccurate or slow counting of ballots, or fiddling with the registration rolls to produce so-called phantom voters or multiple voters'. From the outset, Lee made the government's performance a key election platform by which the public should decide whether or not to vote for the PAP. He maintained that 'The PAP is the Government and the Government is the PAP' (Lew Kuan Yew, as quoted in Milne and Mauzy (1990, p. 85)).

Lee Kuan Yew's governance strategy was based largely on three principles: keep politics out (of economic management), keep performance accountable, and keep the government clean (Root, 1996).

A distinct division of labour was created between the PAP parliamentarians and technocratic government. Bureaucrats had to resign before they could become members of the parliament. Civil servants were not allowed to have any relationships with the private sector. A wellstructured system of accountability was set in place to ensure that public funds were not wasted or misused.

One of the key priorities for the Singaporean government from the outset was 'keeping the government clean'. Lee $(1998,2000)$ viewed corruption as a major obstacle to political stability and governmental effectiveness: 'Only by upholding the integrity of the administration can the economy work in a way which enables Singaporeans to clearly see the nexus between hard work and high rewards' (Lee Kuan Yew, as quoted in Lim (1998)).

Clean government was a premise Lee's People's Action Party used to maintain dominance in Singapore's political arena. Lee believed that this, in turn, would allow the government to focus on the tasks of the country's economic management. One important component of the clean government policy was to pay government employees and politicians good wages to discourage rent-seeking behaviours. Good salaries were also an important component of the strategy to attract top talent into civil service jobs. The focus of the anti-corruption body, the Corrupt Practices Investigation Bureau (CPIB), has been on the higher echelons of power, with a few high-level officials caught and successfully prosecuted. For lower-level corruption, the government focused on streamlining processes and removing decision-making powers, where possible, from lower-level officials. Anti-corruption laws were tightened to help successful prosecution of corruption cases.

One key component of successful governance is ensuring administrative competence at all levels of government and public service. Singapore has put a strategy in place whereby talented individuals were, for example, identified in their university years and attracted into the government sector. The principle of meritocracy was set and rigorously enforced at all levels of government and public service. The criteria for a successful career in government were set beyond good academic results alone. As Lee Kuan Yew put it in a 1965 speech, 'Singapore must get some of its best in each year's crop of graduates into the government. When I say the best, I don't mean just academic results. His ... university degree will only tell you his power of analysis. This is only one third of the helicopter quality. You've then got to assess him for his sense of reality, his imagination, his quality of leadership, his dynamism. But most of all, 
his character and his motivation, because the smarter a man is, the more harm he will do to society' (Han, Fernandez, \& Tan, 1998, pp. 331-342). The task of recruiting the best people to public service, as well as managing such personnel to their best use, was entrusted to the Public Service Commission.

Lee Kuan Yew described his leadership style as one similar to 'a conductor of an orchestra'. He credits his loyal colleagues in the government, particularly founding members of the PAP, Goh Keng Swee, Sinnathamby Rajaratnam and Toh Chin Chye, with the success of the government he led (Lee, 2000). The latter three were all very capable individuals, holding senior positions in government for many years. However, they have not challenged Lee's leadership of the party, which ensured the smooth and efficient operation of the government, free of internal infighting.

With people being a principal resource, the government pushed to ensure that adequate technical training opportunities were created to service a growing manufacturing sector. The number of technical and vocational training places grew rapidly from 1961 to 1967, offering a broad range of courses (Neo \& Chen, 2007). Over time, the need for upskilling to service higher-value sectors brought about the creation of the Skills Development Fund. The fund's purpose was to help employers with the retraining and upskilling of their employees. Much effort was dedicated to strengthening school education, especially in technical disciplines. Students were streamed according to their academic performance and their ability to cope with two languages (English and ethnic language). Particular attention was paid to English, as a language of multiracial communication. Moreover, Lee's government has encouraged study of the Mandarin language within the Chinese community in Singapore in preference to supporting the several regional dialects prevalent at that time. This was a strategic move to ensure an effective channel of communication with China as it emerged as a superpower.

Lee also saw English as a language of cutting-edge technology and trade, and actively supported the idea that university education had to be delivered in English. The only Chineselanguage university switched to English as a language of instruction in 1975 and later merged with the University of Singapore to form the National University of Singapore. Moreover, efforts were made to improve university standards. Talented youth was encouraged to study overseas, with funding made available to support the most promising students in studying in prestigious universities in the US, the UK, Australia and elsewhere.

Chen (1984) has reported a 20-fold increase in government expenditure on education over the period from 1960 to 1982 , with only a 30 per cent increase in student numbers for the same period, a great indicator of the emphasis placed on the development of human capital in Singapore.

Singapore's economic policy in the 1960s was largely driven by three external forces: merger and separation from Malaysia with no prospect of a common market, a poor relationship with Indonesia, and the planned withdrawal of the British military that contributed about 20 per cent to national employment. Following the advice of the Dutch economist Albert Winsemius, the government adopted a strategy of rapid industrialisation by encouraging foreign manufacturers to set up manufacturing facilities in Singapore. To achieve this, the government created the Economic Development Board (EDB), a 'one-stop shop' for foreign investors to deal with all government bureaucracy. Moreover, actions were taken to keep labour costs under control, provide tax incentives, set up designated industrial estates, improve the technical skills of labourers, and ensure free movement of capital (Rodan, 1989). Although any investment was welcome, the government soon realized that the best opportunities in terms of more modern equipment, know-how and marketing techniques came from American multinational corporations (MNCs), and they became a primary target (Lee, 2000; Minchin, 1986). In the 
absence of a regional market, they hoped American (and other) MNCs would use Singapore as an offshore production facility, and assist the country with its export-oriented strategy. By the early 1970s, the strategy had started to pay off, gradually reducing the unemployment rate from 14\% in 1963 to less than $4.5 \%$ by 1974 (Rodan, 1989; World Bank, 2019).

To support government investment in the economy, the government set up the Central Provident Fund (CPF), a compulsory social security scheme for retired workers in Singapore. The scheme has allowed government to access significant funds at below-market rates. It also helped Singaporeans to save for housing, medical expenses and retirement (Beng \& Chew, 2002). The government showed great flexibility in using CPF in its labour policy, increasing contribution rates to boost savings for the necessary expenses, but also lowering rates at times of recession to support the disposable income of the population.

The government ensured that it made good use of the savings. Several government-funded enterprises were set up to support economic growth and employment. A notable feature of these projects was a strict adherence to the principles of commercial viability.

One of the industries to which Prime Minister Lee paid particular attention was finance. The goal was to set up a financial centre that would contribute to the 24-hour global financial market, and would complement Europe (particularly London), the US (New York) and Japan (Tokyo). The Monetary Authority of Singapore, which was established in the 1970s and served as an equivalent to a Singaporean central bank, developed modern rules and regulations to ensure confidence and the integrity of the market. To attract international financial institutions, the government abolished income tax on interest earned by non-resident depositors. Moreover, Singapore started an offshore Asian dollar market with all the Asian dollar deposits exempt from liquidity and reserve requirements. As Lee (2000, p. 73) noted, 'The foundations for the financial centre were the rule of law, an independent judiciary, and a stable, competent, and honest government that pursued sound macroeconomic policies.' These efforts allowed Singapore to become almost the largest financial centre in Asia, only slightly behind Tokyo.

One of the key achievements of Lee's government has been to establish effective relationships with trade unions. The government worked closely with the National Trades Union Congress (NTUC) to ensure that wage growth in Singapore moved in line with productivity improvements. This was critical in attracting and retaining foreign investors' businesses in Singapore. A National Wage Council was set up in 1972 with representatives of government, unions and employers to ensure that workers would receive appropriate compensation without triggering wage spirals.

\section{Assessing reforms in Uzbekistan and Kazakhstan vis-à-vis Singapore}

Uzbekistan and Kazakhstan became independent as a result of the dissolution of the Soviet Union in 1991. Being a part of the Russian Empire and then the Soviet Union, both nations participated fully in the communist experiment that built from the communist revolution of 1917. One of the challenges both countries had to face upon independence was the implementation of market-oriented reforms. Over 70 years of communist ideology and centrally planned economic management meant that there was no expertise in managing a free market economy, very little such expertise in the academic community either, and no experience of the people in either country in living in anything resembling Western democracy with relevant institutions. This represents a stark contrast to Singapore, where British institutions were operational at the time of independence. Although the Singaporean government had to work hard to fend off pressures from communists, the latter were unable to make serious inroads into the rule of law, the independent judiciary, or commercial contract enforcement principles. 
Unfortunately, neither Uzbekistan nor Kazakhstan, in their first 25 years of reforms, were able to establish effective institutions to support a market economy. The European Bank for Reconstruction and Development (2016) provided an assessment of institutional reforms in various sectors of economy: Uzbekistan and Kazakhstan score a lowly 1.59 and 2.25 respectively, where 1 represents no change from a centrally planned economy and 4.3 is the standard associated with an industrialized country.

The Lee Kuan Yew-led government and its People's Action Party, despite their dominance in Singapore since independence, had to face regular elections and prove their merits to the electorate on a regular basis. In Uzbekistan and Kazakhstan, with no history of multi-party elections and no associated experience within the electorate, the communist leaders of the respective republics got elected with relative ease. Karimov, in his first presidential election of December 1991 gained 86\% of the vote, while Nazarbayev was elected unopposed in the same month (Akimov, 2015; Minahan, 1998). Arguably, this first election in Uzbekistan has been the only one with a real opposition. All presidential elections thereafter were against handpicked candidates, while only pro-presidential parties ran in parliamentary elections. Any serious opposition parties and candidates were crushed and not allowed to stand. In those circumstances, all elections in Uzbekistan became a formality, and consequently did not play any role in making the Uzbek government accountable. Similarly, in Kazakhstan, Nazarbayev had consolidated power in his hands by the mid-1990s. Any opposition to the establishment of a strong presidential republic led by him was overcome by repeated dissolution of the parliament, in 1993 and 1995, while attempts to challenge presidential powers by the more liberal Prime Minister, Kazhegeldin, were successfully fended off. Since then, Nazarbayev and pro-presidential parties have faced little opposition in presidential and parliamentary elections. Here too, democratic elections have not played a significant role in keeping government and the president accountable to the people. Both Uzbekistan and Kazakhstan have consistently ranked poorly in Freedom House's (2016) political freedom and civil liberties ratings, with Uzbekistan having the lowest possible scores ( 7 - the least free) in both categories, and Kazakhstan scoring only marginally better with scores of 6 for political freedom and 5 for civil liberties. Singapore has had higher scores (of 4) since the inception of the index (Freedom House, 1991).

Trade unions have never threatened political stability in either Kazakhstan or Uzbekistan. During the Soviet era, they effectively became instruments for the distribution of perks, such as subsidized travel packages to sought-after destinations, access to sanatoria, and free entertainment tickets. They had no ability to consolidate workers against their employers. These trade unions, if anything, became even weaker post-independence. Both countries maintained many aspects of Soviet-style labour laws, and were not configured to provide the flexible work arrangements expected in modern economies.

Lee Kuan Yew's idea of 'keeping politics out' of the economic management of the country has been fully adopted by President Karimov, being emphasized in his books (Karimov, 1996d, p. 63 ; 1996f, p. 166) and rigorously implemented; Karimov was the only person to speak on political matters publicly. In contrast, accountability has never been high on the agenda; the economic statistics were either withheld or notoriously unreliable (Akimov \& Dollery, 2009). The annual performance reports dedicated to discussion of the year-end results were generally full of praise for the achievements of the preceding period. Finally, there has been little effort to combat the problem of corruption in the early years of independence. Thus, on the one hand, Karimov has emphasized the danger of corruption for the country from his earliest speeches (Karimov, 1996a, p. 199; 1996c, p. 221) but, on the other hand, the government formally 
rehabilitated those accused in the so-called 'Cotton case', sending a mixed message to bureaucrats. As a result, corruption became widespread, with a strong impact on all spheres of the economy (US Department of State, 2009b). The country first appeared in the Corruption Perceptions Index in 1999 when it was ranked $94^{\text {th }}$ out of 99 countries with a score of 1.8 (out of 10), and has since remained consistently near the bottom of the index (Transparency International, 2019). The US Department of State's 2009 Investment Climate Report, together with its subsequent reports, have repeatedly cited corruption in Uzbekistan as a major obstacle to attracting foreign direct investment. Singapore's strategy of good remuneration for public sector officers has not been adopted in Uzbekistan; bureaucrats' low pay and red tape are often cited as precursors of widespread corruption.

Similarly, in Kazakhstan, corruption has been publicly acknowledged as a problem and a threat and been deplored (Nazarbayev, 2006). Kazakhstan was the first country in the Central Asian region to adopt an Anti-Corruption Act, in 1998. However, the effectiveness of the legislation was limited. As in Uzbekistan, public sector employees remain poorly paid, thus creating an incentive for bribery and red tape. The country has also been consistently low-ranking in the Corruption Perceptions Index, although it has scored better than Uzbekistan in most of the reported years. The 2003 bribery scandal involving Nazarbayev's economic adviser has stained Nazarbayev's reputation and undermined anti-corruption efforts (Akimov, 2015). Despite the highlighting of corruption issues (US Department of State, 2009a), Kazakhstan has been able to attract foreign direct investment, albeit mainly into the oil and gas sector. Figure 1 illustrates the trends in Corruption Perceptions Indices for Kazakhstan, Uzbekistan and Singapore from the index's inception in 1999 through to 2016.

\section{-INSERT FIGURE 1 HERE-}

Perhaps among the most damaging obstacles to effective governance and public service is the inability of most capable employees to build their careers in the public sector because of inefficiencies, nepotism, cronyism and corruption. Despite public calls from both leaders to avoid nepotism and corruption and promote the most able workers (Karimov, 1996b, p. 66; Kazinform, 2014; Nazarbayev, 2017, pp. 210-211), neither country was able to establish a strong principle of meritocracy. A practice of public rebukes and sackings of regional governors and other high-level officials for mismanagement was popular in Karimov's Uzbekistan, only for those individuals to be re-appointed elsewhere shortly thereafter. In Kazakhstan, the successful public service career of Nazarbayev's daughter, as well as the senior posts held by his two sons-in-law, looked to the public like an 'unofficial' acceptance of nepotism as the norm. Arguably, Nazarbayev has been more systematic and successful in appointing competent and reform-driven personnel to high positions, notably Kazhegeldin in the prime ministerial role in the early 1990s, and Marchenko in leading financial sector reform as the Chief of the National Bank of Kazakhstan.

Education in Kazakhstan was widely regarded as a neglected and less-than-successful area of government activity. Expenditure on education from the national budget dropped to 3-4\% of GDP between 1993 and 2004. With a few exceptions, Kazakhstan's educational institutions were grossly under-resourced and inadequate, especially for a country that aspired to be in the top 50 most competitive economies by 2030. Teachers' skills and morale are at low levels and bribery is widespread (Aitken, 2009; Pomfret, 2019). The notable exception was the Bolashak programme, launched in 1994, which provided scholarships to talented youth to study in Western institutions. Many of its graduates returned to Kazakhstan and are pursuing successful careers in business and government. Moreover, a new Nazarbayev University was set up in

\footnotetext{
${ }^{2}$ A legal case, which publicly revealed the extent of corruption in cotton production and reporting in the Uzbek Soviet Republic in the 1980s.
} 
Astana (now Nursultan) with the assistance of Duke University, with foreign-trained academics delivering Western-style higher education in English. In addition, in 1993, the government allowed establishment of private educational institutions, with a number providing an alternative to poor-quality state universities. Higher education was increasingly delivered in the Kazakh language, which has not encouraged modernization due to the lack of modern scientific literature in the language and delays in translation. Although English-based education grew to $2.6 \%$ of the total, it remains almost negligible (Ahn, Dixon, \& Chekmareva, 2018).

By contrast, Uzbekistan has maintained much higher spending on education than Kazakhstan. Most of this spend was directed to school education, with limited resources allocated to universities. By the end of the 1990s, the government had announced several educational reforms, replacing the eleven-year compulsory school system with a nine-year programme. This was to be complemented by three-year education in technical colleges or academic lyceums as a pathway to university entry. The government spent considerable resources on building new colleges. However, teacher training, textbooks and equipment were inadequate and lagged behind. Moreover, complaints of inefficiency, corruption and falling standards started to emerge (Pomfret, 2019). The government maintained a strong grip on education and was reluctant to allow private providers to enter the market. Notable exceptions were a small number of foreign university branches, particularly Westminster International University in Tashkent (WIUT). The government ran a similar program to Bolashak in the late 1990s and early 2000s. However, this 'Umid' foreign-study programme was effectively closed with the opening of WIUT in 2002. Because of government restrictions, tertiary enrolment has remained low in comparison to other countries (Ruziev \& Burkhanov, 2018).

In addition, the shifting of education to the Uzbek language and the Latinisation of the Uzbek alphabet put a great burden on the resources required to regenerate educational materials. With limited resources and personnel, it was impossible to do quickly, further restricting modernisation in the sector.

Post-independence, Uzbekistan has adopted a very gradual approach to economic reform. Karimov's goal was to maintain and/or restore manageability of an economy facing the breaking of links with other countries of the Soviet Union. Prices were gradually liberalized, and by 1996 housing and small enterprises had been privatized. Inflation remained a problem throughout the 1990s (Akimov \& Dollery, 2009; Pomfret, 2006). There was little success in attracting foreign direct investment because so many restrictions remained in place.

After the resumption of foreign-exchange controls in 1997, Uzbekistan's pursuit of an importsubstitution policy became more open. Although industrialization was on the government agenda, with flagship projects such as the Daewoo automotive plant in Asaka, many older manufacturing facilities were either scaling down or closing. The share of manufacturing in the economy declined from 28 per cent in 1987 to 9 per cent in 2010 (Pomfret, 2019).

Agriculture remained an important sector of the economy with cotton-farming being one of the most significant, despite being a declining source of export revenue for the government. Mining, particularly for gold and natural gas, was another important source. The financial sector was dominated by state-owned banks, particularly the National Bank of Uzbekistan, with little competition in the sector and a lack of trust on the part of the population (Akimov \& Dollery, 2006). There have not been any serious attempts to reform the pension system in Uzbekistan; the system remains largely tax-funded, with individual contributions to personal pension accounts too small to make a substantial difference.

The outcome of these economic reforms has been mixed. The cautious and gradual approach to reforms in the early 1990s paid off in the fastest recovery of the post-Soviet countries. 
However, the reform reversals from 1997 onwards and a lack of substantive reforms in the 2000s led to slower economic growth than in some other countries in the region. Clearly, in terms of economic indicators such as GDP per capita, Uzbekistan lagged ever further behind neighbouring Kazakhstan, and did not bear comparison with countries like Singapore. The business environment remained subdued as country remained at the bottom section of the World Bank (2015) Ease of Doing Business Ranking until Karimov's death. The country was ranked 141th out of 189 in 2015. Rapid population growth and a lack of economic opportunities inside Uzbekistan led to a mass migration of labour from Uzbekistan to Russia, Kazakhstan and other countries (Kakhkharov, Akimov, \& Rohde, 2017).

Kazakhstan's approach to economic reforms was less gradual than Uzbekistan's. It moved faster in terms of liberalization of prices and privatization of enterprises. Privatization of the oil and gas sector in the 1990s was associated with widespread corruption but delivered substantial foreign direct investment (Pomfret, 2006). The government used a practice of management contracting in which foreign managers were invited in to run large enterprises, especially in the oil and gas industry. The GDP share for the private sector grew rapidly, from 25\% in 1995 to 65\% in 2002 (European Bank for Reconstruction and Development, 2003).

Such changes in the oil and gas industry, including revenue-sharing arrangements with foreign owners, created an excellent platform from which to benefit from rapidly rising hydrocarbon prices in the 2000s and to deliver fast economic growth to Kazakhstan. However, the often opaque and unfair privatization of the industry may have had negative longer-term consequences for the establishment of the rule of law (Pomfret, 2019).

After the early years of chaos, the financial sector had been strengthened by the end of the 1990s (Akimov \& Dollery, 2008). Kazakhstan was the first post-Soviet republic to introduce a privately funded pension programme, in 1998. The reform helped to boost development of the financial sector and enabled the opening of private pension funds. The reform was partially reversed after the Global Financial Crisis, which saw private pension funds closed and citizens' accounts incorporated into the public pension fund.

In contrast to Uzbekistan, Kazakhstan also faced a large population decline in the 1990s, mainly caused by the emigration of well-educated ethnic Russians and Germans. This trend, although relieving the separatist moods in the country's northern regions, then dominated by ethnic Russians, had a strong negative impact on the manufacturing sector.

Kazakhstan benefitted greatly from its natural resource endowment and policies that stimulated investments in the sector, which resulted in double-digit economic growth in the 2000s. Despite a slow start in the 1990s, the country became the regional leader in the early 2000s, bringing improvements in living standards. However, the global financial crisis has shaken confidence in the strategy. Falling energy prices led to reduced state revenues, while the financial sector was hit hard by reckless lending practices and a reliance on cheap foreign short-term debt. The share of the value-added mining sector (as a percentage of GDP) grew from 15.39 per cent in 1995 to a peak of 29.28 per cent in 2010 , before falling back to 20.65 per cent in 2016 . Manufacturing has been registering a steady decline since 1995. The government, to its credit, recognised the problem and put an effort in improving the business environment, which has reflected in the improved scores in the World Bank $(2006$; 2016) Ease of Doing Business Ranking. The country has moved from 86th place in 2006 to 41th in 2016.

In a social sphere

Comparative statistics for the post-independence economic performance of Singapore, Kazakhstan and Uzbekistan are presented in Table 1. The data for Singapore covers the period 
under the leadership of Lee Kuan Yew, from 1965 to 1990, whereas that for Kazakhstan and Uzbekistan covers the period of 1991 to 2016.

-INSERT TABLE 1 HERE-

As is evident from Table 1, Singapore has been able to achieve much more impressive economic growth rates, with a 5.52-fold growth in GDP per capita compared to around 2-fold for both Kazakhstan and Uzbekistan. It has done this initially through better investments in manufacturing facilities, and latterly in cutting-edge services. Thanks to its unique location on a maritime crossroads and its small size, Singapore had no viable choice but to develop an export-oriented economy, where trade plays a much greater role. Economic growth in Singapore brought improvements in social standards and human development, moving it from a Third World economy to a First World one. Having had higher human development levels at independence, social development indicators in Kazakhstan and Uzbekistan have shown far less improvement, due to lower expenditure in social services (in Kazakhstan) or ineffective use of resources and inconsistent quality of services such as education and healthcare (in both countries).

\section{Conclusion}

At the time of independence, the Central Asian republics of Kazakhstan and Uzbekistan dismissed the idea of building Western-style liberal democracies, arguing that they would not fit well with local cultural traditions and values. Instead, they looked to the experiences of successful Asian economies for inspiration. Thus, Singapore's impressive transformation under the authoritarian leadership of Lee Kuan Yew might serve as a useful vehicle of comparison. Kazakhstan's Nazarbayev, explicitly citing Lee Kuan Yew as one of his early mentors, has indeed adopted a number of similar economic policies, in particular, attracting foreign direct investment. Uzbekistan's Karimov, although not specifically citing the Singaporean leader as an example, voiced many ideas that resembled those adopted by Lee. However, some of the key ingredients in the economic success of Singapore were not implemented in either of these countries.

Neither Karimov nor Nazarbayev were able to keep their governments clean. Corruption grew out of control in the early years of independence and remains a major challenge to any reforms. Both Uzbek and Kazakh leaders were able to achieve political stability through their domination of the political landscape. However, unlike Singapore, this was not through fair and democratic elections, which also serve as a good tool of discipline when it comes to holding governments and leaders accountable for their actions.

After 25 years of reforms, Kazakhstan and, in particular, Uzbekistan continue to face serious human resource shortages. At the time of independence, the lack of market institutions and of competent administrators capable of introducing market reforms were objective challenges. Unfortunately, due to widespread nepotism, neither country was able to nurture a large enough pool of talented and capable managers and public servants to address such challenges. Given this absence of meritocratic career prospects, many have left their countries in search of better opportunities abroad.

In terms of economic policies, Uzbekistan and Kazakhstan have not adopted export-oriented industrialization strategies. This was a partial consequence of unfavourable geographical location, with no direct access to maritime routes and their distance from major consumer markets. Kazakhstan used its vast mineral resources to its advantage in the 2000s, but was largely unable to build alternative industries. Uzbekistan has done even worse as its importsubstitution and protectionist policy failed to create internationally competitive industries besides the extraction of some mineral resources and sales of agricultural products. 
After the death of Karimov in 2016, the new Uzbek president, Mirziyoyev, appears to have chosen a different approach and reversed the policy of isolationism. He put significant efforts into improving relationships with neighbours and travelled extensively in search of foreign investors. Moreover, a series of liberalizing reforms have been introduced, although no talk of establishing a Western-style liberal democracy is expected. Instead, the approach of economic pragmatism seems to be his adopted modus operandi. In that sense, Lee Kuan Yew's legacy is still alive in Uzbekistan.

The new Kazakh president, Tokayev, elected after Nazarbayev's retirement in early 2019, has not yet signposted any significant shifts from current policies. Because Nazarbayev's influence on politics and decision-making remains significant, it may take time for the new Kazakh leadership to manifest its intentions.

\section{References}

Ahn, E. S., Dixon, J., \& Chekmareva, L. (2018). Looking at Kazakhstan's Higher Education Landscape: From Transition to Transformation Between 1920 and 2015. In J. Huisman, A. Smolentseva, \& I. Froumin (Eds.), 25 Years of Transformations of Higher Education Systems in Post-Soviet Countries: Reform and Continuity (pp. 199-227). Cham: Palgrave Macmillan.

Aitken, J. (2009). Nazarbayev and the Making of Kazakhstan. London: Continuum.

Akimov, A. (2015). The politcal economy of financial reforms in authoritarian transition economies: A comparative study of Kazakhstan and Uzbekistan. In K. Ruziev \& N. Perdikis (Eds.), Development and Financial Reform in Emerging Economies. (pp. 125-148). London: Pickering \& Chatto.

Akimov, A., \& Dollery, B. (2006). Uzbekistan's financial system: Evaluation of twelve years of transition. Problems of Economic Transition, 48(12), 6-31.

Akimov, A., \& Dollery, B. (2008). Financial system reform in Kazakhstan from 1993 to 2006 and its socioeconomic effects. Emerging Market Finance and Trade, 44(3), 81-97.

Akimov, A., \& Dollery, B. (2009). Financial development policies in Uzbekistan: An analysis of achievements and failures. Economic Change and Restructuring, 42(4), 293-318.

Beng, C. S., \& Chew, R. (2002). Managing the Singapore Economy. In K. T. Liou (Ed.), Managing Economic Development in Asia: From Economic Miracle to Financial Crisis (pp. 65-92). Westport: Praeger.

Chen, P. S. (1984). Social change and economic planning. In P. S. You \& C. Y. Lim (Eds.), TwentyFive Years of Development (pp. 315-338). Singapore: Nan Yang Xing Zhou Lianhe Zaobao.

European Bank for Reconstruction and Development. (2003). Transition Report 2003: Integration and Regional Cooperation. London: EBRD.

European Bank for Reconstruction and Development. (2016). Transition Report 2016-17. Transition for all: Equal opportunities in an unequal world. London: EBRD.

Freedom House. (1991). Freedom in the World: Political Rights \& Civil Liberties 1990-1991. New York: Freedom House.

Freedom House. (2016). Freedom in the World 2016. Anxious Dictators, Wavering Democracies: Global Freedom under Pressure. Washington, DC: Freedom House.

Han, F. K., Fernandez, W., \& Tan, S. (1998). Lee Kuan Yew: The Man and His Ideas. Singapore: The Straits Times Press.

Josey, A. (1980). Lee Kuan Yew: The Struggle for Singapore (3rd ed.). Singapore: Angus \& Robertson.

Kakhkharov, J., Akimov, A., \& Rohde, N. (2017). Transaction costs and recorded remittances in the post-Soviet economies: Evidence from a new dataset on bilateral flows. Economic Modelling, 60(January), 98-107. 
Karimov, I. (1996a). Economic Reforms: the crucial stage. Speech in front of Bukhara Regional Council of Deputies on 18 March 1994. In Our Aim is Free and Prosperous Motherland (pp. 174-201). Tashkent: Uzbekiston.

Karimov, I. (1996b). The Motherland's interests are above all. Speech at Syrdarya Council of Deputies on 9 October 1993. In Our Aim is Free and Prosperous Motherland (pp. 56-68). Tashkent: Uzbekiston.

Karimov, I. (1996c). Our Path is the Path of Indepent Statehood and Progress. Speech on 15th session of Supreme Council of Republic of Uzbekistan on 5 May 1994. In Our Aim is Free and Prosperous Motherland (pp. 210-231). Tashkent: Uzbekiston.

Karimov, I. (1996d). Uzbekistan: On the Way of Deepening of Economic Reforms. In The Motherland Must be Holy for Everyone (pp. 164-348). Tashkent: Uzbekiston.

Karimov, I. (1996e). Uzbekistan: Own Model of Transition to Market Relations. In Uzbekistan: Nation's Independence, Economy, Politics and Ideology (pp. 263-343). Tashkent: Uzbekiston.

Karimov, I. (1996f). Uzbekistan: Own Way for Revival and Progress. In Uzbekistan: Nation's Independence, Economy, Politics and Ideology (pp. 36-81). Tashkent: Uzbekiston.

Kazinform. (2014, Oct 6). Kazakh president warns officials against nepotism in hiring staff. $B B C$ Monitoring Central Asia.

Lee, K. Y. (1998). The Singapore Story: Memoirs of Lee Kuan Yew. Singapore: Prentice Hall.

Lee, K. Y. (2000). From Third World to First. The Singapore Story: 1965-2000. New York: Harper Collins.

Lim, S. G. (1998). Integrity with empowerment: Challenges facing Singapore in combating corruption in the 21st century. Retrieved from https://www.csb.gov.hk/mobile/pdf/english/conference_meterials/1998_lim.pdf

Milne, R. S., \& Mauzy, D. K. (1990). Singapore: The Legacy of Lee Kuan Yew. Boulder: Westview Press.

Minahan, J. (1998). Miniature Empires: A Historical Dictionary of the Newly Independent States. New York: Routledge.

Minchin, J. (1986). No Man is an Island: A Study of Singapore's Lee Kuan Yew. Sydney: Allen \& Unwin.

Nazarbayev, N. (2006). The Kazakhstan's Way (in Russian). Karaganda: Arko.

Nazarbayev, N. (2017). Era of Independence. Astana.

Neo, B. S., \& Chen, G. (2007). Dynamic Governance: Embedding Culture, Capabilities and Change in Singapore. Singapore: World Scientific Publishing.

Pomfret, R. (2006). The Central Asian Economies Since Independence. Princeton: Princeton University Press.

Pomfret, R. (2019). The Central Asian Economies in the Twenty-first Century: Paving a New Silk Route. Princeton: Princeton University Press.

Rodan, G. (1989). The Political Economy of Singapore's Industrialization: National State and International Capital. Basingstoke: Macmillan.

Root, H. (1996). Small Countries, Big Lessons: Governance and the Rise of East Asia. Hong Kong: Oxford University Press.

Ruziev, K., \& Burkhanov, U. (2018). Uzbekistan: Higher Education Reforms and the Changing Landscape Since Independence. In J. Huisman, A. Smolentseva, \& I. Froumin (Eds.), 25 Years of Transformations of Higher Education Systems in Post-Soviet Countries: Reform and Continuity (pp. 435-459). Cham: Palgrave Macmillan. 
Transparency International. (2019). Corruption Perceptions Index. Retrieved from https://www.transparency.org/research/cpi/cpi_early/0

Tremewan, C. (1996). The Political Economy of Social Control in Singapore. Basingstoke: Macmillan. US Department of State. (2009a). 2009 Investment Climate Statement - Kazakhstan. Retrieved from https://2009-2017.state.gov/e/eb/rls/othr/ics/2009/117170.htm

US Department of State. (2009b). 2009 Investment Climate Statement - Uzbekistan. Retrieved from https://2009-2017.state.gov/e/eb/rls/othr/ics/2009/117170.htm

Wintrobe, R. (1998). The Political Economy of Dictatorship. Cambridge: Cambridge University Press.

Wirtz, J., \& Chung, C. (2006). Singapore: Marketing, macro trends, and their implications for marketing management for 2005 and the years beyond. In A. Pecotitch \& C. Shultz II (Eds.), Handbook of Markets and Economies: East Asia, Southeast Asia, Australia, New Zealand. New York: M.E. Sharpe.

World Bank. (2006). Doing Busines 2006: Creating Jobs. Washington, DC: World Bank. Retrieved from: https://www.doingbusiness.org/content/dam/doingBusiness/media/Annual-

Reports/English/DB06-FullReport.pdf

World Bank. (2015). Doing Busines 2015: Going Beyong Efficiency. Washington, DC: World Bank. Retrieved from: https://www.doingbusiness.org/content/dam/doingBusiness/media/Annual-

Reports/English/DB15-Full-Report.pdf

World Bank. (2016). Doing Busines 2016: Measuring Regulatory Quality and Efficiency. Washington, DC: World Bank. Retrieved from:

https://www.doingbusiness.org/content/dam/doingBusiness/media/Annual-Reports/English/DB16-

Full-Report.pdf

World Bank. (2019). World Development Indicators Online. Retrieved from https://databank.worldbank.org/reports.aspx? source=world-development-indicators

Yusuf, S., \& Nabeshima, K. (2002). Some Small Countries Do It Better: Rapid Growth and Its Causes in Singapore, Finland, and Ireland. Washington, DC: World Bank Publications. 
Table 1. Comparative post-independence economic performance of Singapore and Kazakhstan and Uzbekistan

\begin{tabular}{|c|c|c|c|c|c|c|c|}
\hline & 1965 [1991] & 1970 [1996] & 1975 [2001] & 1980 [2006] & 1985 [2011] & $1990[2016]$ & Change \% \\
\hline \multicolumn{8}{|c|}{ GDP per capita (constant 2010 US\$) } \\
\hline SG & 4088 & 6787 & 9674 & 13534 & 16633 & 22572 & 552 \\
\hline $\mathrm{KZ}$ & 5210 & 3814 & 5107 & 7917 & 9603 & 10583 & 203 \\
\hline $\mathrm{UZ}$ & 977 & 731 & 842 & 1061 & 1452 & 1909 & 195 \\
\hline \multicolumn{8}{|c|}{ Foreign direct investment, net inflows (\% of GDP) } \\
\hline SG & .. & 4.84 & 5.18 & 10.39 & 5.46 & 15.42 & \\
\hline KZ & $0.40 *$ & 5.41 & 12.72 & 9.40 & 7.14 & 12.54 & \\
\hline $\mathrm{UZ}$ & $0.07 *$ & 0.65 & 0.73 & 1.00 & 3.56 & 2.03 & \\
\hline \multicolumn{8}{|c|}{ Gross fixed capital formation (\% of GDP) } \\
\hline SG & 20.95 & 32.12 & 34.89 & 39.52 & 40.79 & 31.72 & 10.77 \\
\hline $\mathrm{KZ}$ & $30.43^{*}$ & 17.23 & 23.73 & 30.20 & 21.46 & 22.72 & -7.71 \\
\hline $\mathrm{UZ}$ & $43.93 *$ & 23.00 & 26.82 & 21.63 & 25.71 & 22.83 & -21.10 \\
\hline \multicolumn{8}{|c|}{ Industry, value-added (\% of GDP) } \\
\hline SG & 22.15 & 26.93 & 31.21 & 34.88 & 32.17 & 30.86 & 8.71 \\
\hline $\mathrm{KZ}$ & $38.97 *$ & 25.59 & 36.14 & 39.36 & 37.27 & 31.98 & -6.99 \\
\hline $\mathrm{UZ}$ & 36.68 & 26.08 & 19.95 & 26.84 & 29.92 & 24.14 & -12.54 \\
\hline \multicolumn{8}{|c|}{ Services, value-added (\% of GDP) } \\
\hline SG & 69.20 & 65.02 & 63.08 & 59.90 & 63.14 & 64.18 & -5.02 \\
\hline $\mathrm{KZ}$ & $25.12 *$ & 58.04 & 49.37 & 51.64 & 48.89 & 57.86 & 32.73 \\
\hline $\mathrm{UZ}$ & 26.54 & 37.12 & 38.21 & 37.96 & 43.68 & 35.77 & 9.23 \\
\hline \multicolumn{8}{|c|}{ Trade (\% of GDP) } \\
\hline SG & 257.54 & 271.06 & 283.57 & 410.94 & 304.14 & 344.33 & \\
\hline $\mathrm{KZ}$ & $149.34 *$ & 71.27 & 92.85 & 91.45 & 73.12 & 60.31 & \\
\hline $\mathrm{UZ}$ & .. & .. & 56.78 & 67.47 & 63.49 & 29.75 & \\
\hline \multicolumn{8}{|c|}{ Life expectancy at birth, total (years) } \\
\hline SG & 67.09 & 68.28 & 70.22 & 72.19 & 73.89 & 75.30 & 8.21 \\
\hline $\mathrm{KZ}$ & 67.98 & 64.11 & 65.77 & 66.16 & 68.98 & 72.30 & 4.32 \\
\hline $\mathrm{UZ}$ & 66.42 & 66.49 & 67.37 & 68.66 & 70.32 & 71.31 & 4.89 \\
\hline
\end{tabular}

*Data for 1992

Source: World Bank (2019) 


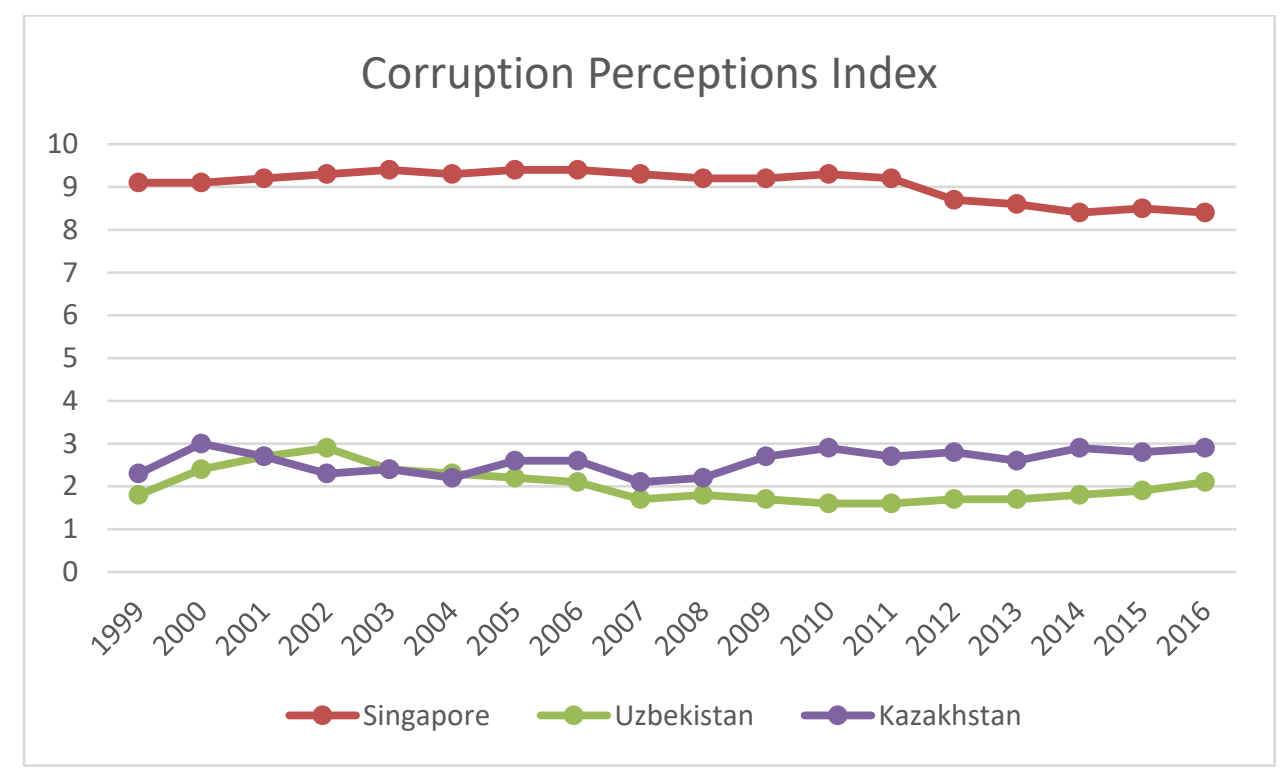

Figure 1. Corruption in Singapore, Kazakhstan and Uzbekistan.

Source: Transparency International (2019) 